Pak. j. sci. ind. res. Ser. A: phys. sci. 2021 64A(1) 35-45

\title{
Assessing Impact of Naphthalene Acetic Acid on the Growth and Yield of Okra (Abelmoschus esculentus (L.) Moench)
}

\author{
Muhammad Nisara, Habib Ur Rahmana, Muhammad Sohail Khan**, Ilham Khan ${ }^{\mathrm{b}}$, \\ Saba Fatima ${ }^{a}$, Kashif Waseema and Khalid Rahman ${ }^{a}$ \\ ${ }^{a}$ Department of Horticulture, Faculty of Agriculture, Gomal University, \\ Dera Ismail Khan, Khyber Pakhtunkhwa, Pakistan \\ bInstitute of Chemical Sciences, Gomal University, Dera Ismail Khan, Khyber Pakhtunkhwa, Pakistan
}

(received June 11, 2019; revised January 23, 2020; accepted February 3, 2020)

\begin{abstract}
This study assessed the impact of naphthalene acetic Acid (NAA) on the growth and yield of Okra cv. Sabz Pari at Agricultural Research Institute, Dera Ismail Khan, Khyber Pakhtunkhwa, Pakistan. A field experiment was set out in randomised complete block design with NAA application as a main factor. Different NAA concentrations were obtained by dissolving NAA in distilled water at the rate of 0 (control), 10, 30, 50, 70, 90 and $110 \mathrm{mg} / \mathrm{L}$. NAA treatments along with control were foliar applied to okra plants after 30 days of sowing. Lower concentration of NAA $(30-50 \mathrm{mg} / \mathrm{L})$ stimulated maximum increase in plant height (59.5-57.2\%), number of leaves/plant (50.4-45.5\%,), total plant leaf area (113.9-119.4\%), internodes/plant (72.5-61.6\%), internode length (53.2-44.5\%), pod diameter (53.5-49.9\%), pod fresh weight (126.8-111.8\%), pod yield (271.2-255.8\%) compared to control ( $0 \mathrm{mg} \mathrm{NAA} / \mathrm{L})$. NAA at higher concentrations $(>50 \mathrm{mg} / \mathrm{L})$ had a supressing effect on most parameters. It was inferred that yield production in okra is influenced by multiple yield-determining component traits and their mutual interactions which could be manipulated by the application of NAA. Foliar application of NAA $(30-50 \mathrm{mg} / \mathrm{L})$ have a beneficial impact on plant characters and yield of Okra, hence recommended in Okra cultivation.
\end{abstract}

Keywords: Abelmoschus esculentus, NAA, component traits, foliar application, growth, pod yield

\section{Introduction}

Okra (Abelmoschus esculentus L. Moench) is a monetarily critical crop, indeterminate in nature and widely grown in tropical and subtropical regions of the world (Gemede et al., 2015). The crop is produced for tender pods (fruits) which can be harvested over multiple times. It is far more nutritious than tomato, brinjal, and several other cucurbits with average nutritive value of 3.21 (Adelakun and Oyelade, 2011). The pods are highly nutritious and a very good source of dietary fibre, protein, phosphorus, potassium, zinc, copper, calcium, magnesium, manganese, and fair amount of vitamins viz., thiamine, riboflavin, niacin, ascorbic acid, etc., (USDA Nutrient Database for Standard Reference, 2018). The immature pods (fresh or dried) are consumed as boiled or fried vegetables, as soup thickeners as well as used in salads and stews (Yadev and Dhankhar, 2002). Hence, Okra is a worthful crop ensuring excellent means of livelihood to small-scale farmers.

Okra is mostly grown in areas with plentiful sunlight throughout the day. It prefers loamy to sandy loam soils, however, heavier soils with good drainage capacity can

*Author for correspondence; E-mail: sohail.wur@gmail.com produce well. It can tolerate a wide range of soil $\mathrm{pH}$, but prefers soil with a $\mathrm{pH}$ ranging between 6.0-6.8. Soil-based NPK fertilizer application has been reported to ensure good yield in Okra (Babatola, 2006).

Despite the wider production and numerous uses of Okra, there are many constraints contributing to the lower yields, some major ones include soil infertility, limited irrigation resources, adverse environmental conditions leading to unwanted abscission of floral bud and/or developing fruit (Iderawumi et al., 2017), etc. For normal growth an production, Okra crop need a temperature between $24^{\circ} \mathrm{C}$ and $28^{\circ} \mathrm{C}$ (Benchasri, 2012). Seed germination is delayed and decreased, at higher temperatures beyond $38^{\circ} \mathrm{C}$ to $42^{\circ} \mathrm{C}$, flowers may parch and drop, causing yield loss. Despite its considerable tolerance to drought, the crop requires good availability of soil water for optimum growth. High yield reduction has been shown in the water stressed plants (Gunawardhana and de-Silva, 2011). In such situations, exogenous application of plant growth regulators (PGRs) have been found to be effective and useful (Husen et al., 2016; Liu et al., 2014), if applied in suitable forms and at appropriate concentrations. 
The PGRs are known to modify and regulate many growth and physiological processes in plants (Raddadi et al., 2008). They can improve the physiological efficiency of plants such as enhancing the photosynthetic ability of plants as well as stimulating the translocation of photo-assimilates to yield related plant components due to better source-sink relationships and, thereby increasing the overall crop productivity (Dawood and Sadak, 2008). The PGRs have therefore, been known to be one of the quick means of increasing production (Maity et al., 2016).

Auxins are considered an important group of PGRs (Anjum et al., 2011) which play a vital role in cell multiplication and enlargement, adventitious roots formation (Majda and Robert, 2018), apical dominance (Abdoli et al., 2013), and inducing flowering (Malik, 1999). Naphthalene acetic acid (NAA) is among one of the most beneficial PGRs in auxin family. Studies have shown that NAA plays a key function in improving the growth, yield as well as quality of the produce (Singh et al., 2017).

Although, PGRs have great potential, their application, optimal concentration, and plant species specificity have not been fully assessed in important vegetable crops and particularly in Okra. Along these lines, taking into account the positive role of PGRs, this study was designed to determine the impact of exogenous application of NAA on the pod yield including pod quality attributes by optimizing the concentration of NAA.

\section{Materials and Methods}

Plant material. A certified Okra cv. "Sabz Pari" was used in this study. It is early maturing ( $<90$ days) with light green pod colour (Fatima et al., 2019; Khan et al., 2013).

Field experiment. The field experiment was conducted to assess yield formation in aforementioned Okra variety in two consecutive growing seasons (March-July) of 2014 and 2015 referred to as $\mathrm{GS}_{1}$ and $\mathrm{GS}_{2}$, respectively throughout the text. The experimental site was under the auspices of Agricultural Research Institute, Dera Ismail Khan, Khyber Pakhtunkhwa, Pakistan and situated between latitude $31^{\circ} 52^{\prime} \mathrm{N}$, longitude $70^{\circ} 53^{\prime} \mathrm{E}$ with altitude of $182 \mathrm{~m}$ from sea level.

The experiment was set out in a randomised complete block design with different NAA treatments replicated thrice. Six NAA solutions were obtained by dissolving NAA in distilled water using concentrations of 10, 30, $50,70,90$, and $110 \mathrm{mg} / \mathrm{L}$ along with control $(0 \mathrm{mg}$ NAA/L) having distilled water only. Ethanol $(10 \mathrm{~mL})$ was used to facilitate the dissolution process.

The experimental site was assessed for basic physicochemical soil properties prior to execution of the experiment (Table 1). Soil samples were air-dried, ground in a mortar and pestle and screened through $\geq$ $2 \mathrm{~mm}$ mesh for measuring the soil texture (Koehler et al., 1984). Soil $\mathrm{pH}$ was assessed by hand-held $\mathrm{pH}$ meter (JENWAY-3020). Electrical conductivity (EC) was evaluated via conductivity meter (inoLab). Soil organic matter (OM) content (Nelson and Sommers, 1982), ammonium-N, nitrate-N, total N (Keeney and Nelson, 1982), phosphorus (Olsen and Sommers, 1982), and potassium (Knudsen et al., 1982) contents were also ascertained. Soil properties did not vary considerably between the two growing seasons. The soil was a clayloam, marginally alkaline ( $\mathrm{pH}: 7.15-7.51$ ), salt-free (EC: $140-170 \mu \mathrm{S} / \mathrm{cm}$ ), short in OM (0.93-1.01\%), appropriate regarding ammonium-N $(9.21-9.37 \mathrm{mg} / \mathrm{Kg})$, nitrate- $\mathrm{N}(7.89-8.05 \mathrm{mg} / \mathrm{Kg})$, total $\mathrm{N}(0.089-0.096 \%)$, potassium $(157-163 \mathrm{mg} / \mathrm{Kg})$ contents and rich in phosphorus (43.64-45.13 mg/Kg).

Standard cultivation practices were used in seedbed preparation. $\mathrm{N}(120 \mathrm{Kg} / \mathrm{ha})$, phosphorus $(90 \mathrm{Kg} / \mathrm{ha})$, and potassium $(60 \mathrm{Kg} / \mathrm{ha}$ ) were incorporated before seed sowing as urea, single super phosphate (SSP), and

Table 1. Pre-planting physical and chemical properties of the soil.

\begin{tabular}{llll} 
Parameters & $\mathrm{Unit}$ & $\mathrm{GS}_{1}{ }^{\dagger}$ & $\mathrm{GS}_{2}{ }^{\dagger}$ \\
\hline $\begin{array}{l}\text { AB-DTPA extractable } \\
\text { phosphorus }\left(\mathrm{P}_{2} \mathrm{O}_{5}\right)\end{array}$ & $\mathrm{mg} / \mathrm{Kg}$ & 45.13 & 43.64 \\
$\begin{array}{l}\text { Ammonium acetate } \\
\text { extractable potassium }\left(\mathrm{K}_{2} \mathrm{O}\right)\end{array}$ & $\mathrm{mg} / \mathrm{Kg}$ & 163 & 157 \\
$\begin{array}{l}\text { Ammonium nitrogen } \\
\text { (NH} 4-\mathrm{N})\end{array}$ & $\mathrm{mg} / \mathrm{Kg}$ & 9.37 & 9.21 \\
$\begin{array}{l}\text { Nitrate nitrogen }\left(\mathrm{NO}_{3}-\mathrm{N}\right) \\
\text { Total nitrogen }\end{array}$ & $\mathrm{mg} / \mathrm{Kg}$ & 8.05 & 7.89 \\
$\begin{array}{l}\text { Organic Matter }(\mathrm{OM}) \\
\text { pH }\end{array}$ & $\%$ & 0.096 & 0.089 \\
$\begin{array}{l}\text { Electrical Conductivity }(\mathrm{EC}) \\
\text { Texture class }\end{array}$ & $\mu \mathrm{S} / \mathrm{cm}$ & $\begin{array}{l}1.01 \\
170\end{array}$ & 0.93 \\
& - & $\begin{array}{l}\text { Clay- } \\
\text { loam }\end{array}$ & $\begin{array}{l}\text { Clay- } \\
\text { loam }\end{array}$ \\
\hline \hline
\end{tabular}

$\dagger=$ Growing season of 2014; $\ddagger=$ Growing season of 2015. 
sulphate of potash (SOP), respectively. Nitrogen was given in two equal split doses, first at time of planting and second at the onset of flowering. Seeds were presoaked in distilled water before sowing for $24 \mathrm{~h}$ to ensure consistent germination. The pre-germinated seeds were planted on ridges $60 \mathrm{~cm}$ apart and maintaining 30 $\mathrm{cm}$ intra-row spacing. Each block consisted of seven plots of afore-mentioned treatments making total of 21 plots across the three replicates. There were 4 ridges per treatment plot each possessing 10 plants thereby constituting the net plot size of $7.2 \mathrm{~m}^{2}(2.4 \times 3 \mathrm{~m})$ with a total of 40 plants.

NAA treatments along with control were applied to each plot after 30 days of sowing by foliar application with the help of atomizer (Unamba et al., 2009). An adhesive Tween-20 (0.1\%) was added to each solution according to Roy et al. (1991). Control plots were treated only with distilled water. Crop was managed well to avoid any kind of plant stress.

Meteorological temperature and precipitation data were collected from a local weather station during both the growing seasons (Fig. 1). The average monthly air temperature in $\mathrm{GS}_{1}$ (March-July) was 18.0 to $33.0^{\circ} \mathrm{C}$, whereas it ranged from 19.0 to $32.5^{\circ} \mathrm{C}$ in $\mathrm{GS}_{2}$. The total precipitation was 248.5 and $156.5 \mathrm{~mm}$ during the growing season $\mathrm{GS}_{1}$ and $\mathrm{GS}_{2}$, respectively. This clearly indicated that the weather during $\mathrm{GS}_{1}$ was comparatively wetter than $\mathrm{GS}_{2}$.

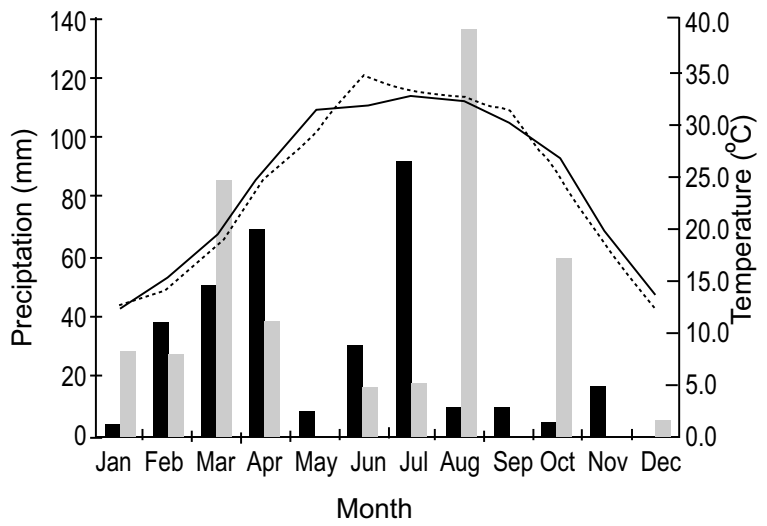

Precipitation $\mathrm{GS}_{1} \quad$ Precipitation $\mathrm{GS}_{2}$ ..... Tmean $\mathrm{GS}_{1}$ - Tmean $\mathrm{GS}_{2}$

Fig. 1. Meteorological trends during two growing seasons of Okra (i.e., $\mathrm{GS}_{1}=2014 ; \mathrm{GS}_{2}=$ 2015).
Measurements. Data were compiled on a range of parameters shaping vegetative and reproductive growth, pod characteristics and yield during the crop cycle in two growing seasons. Plant height $(\mathrm{cm})$, leaves/plant, total plant leaf area $\left(\mathrm{cm}^{2}\right)$, internodes/plant, and internode length $(\mathrm{cm})$ were noted at time of first flowering. The onset of first flowering was estimated at commencement of $50 \%$ plants' flowering. Pod length $(\mathrm{cm})$, pod diameter $(\mathrm{mm})$, and pod fresh weight $(\mathrm{g})$ was noted at every picking and mean value was estimated. Total pods/plant and pod yield $(\mathrm{t} / \mathrm{ha})$ were estimated from the summation of all pickings made. Standard rules developed by the International Union for the Protection of New Varieties of Plants (UPOV, 2018) and The International Plant Genetic Resources Institute (IPGRI, 1991) were adopted for all parameters measuring.

Statistical analysis. Recorded data were analysed statistically in Genstat (Payne et al., 2009). A preliminary analysis of data indicated non-significant differences between the two growing seasons (data not shown). Therefore, a general one-way analysis of variance (ANOVA) technique for each growing season was followed to test the extent and significance of variations among NAA treatments. Differences among treatments means were compared through Fisher's multiple comparison test using 5\% probability level. Pearson correlations were quantified to appraise the interrelationships among the parameters.

\section{Results and Discussion.}

Assessing impact of NAA on vegetative growth of Okra. Various concentrations of NAA had highly significant $(\mathrm{P} \leq 0.001)$ impact on parameters determining the vegetative growth of Okra in both growing seasons (i.e. $\mathrm{GS}_{1}$ and $\mathrm{GS}_{2}$ ). In $\mathrm{GS}_{2}$, NAA at $30 \mathrm{mg} / \mathrm{L}$ produced the maximum plant height $(84.0 \mathrm{~cm})$, leaves/plant $(29.1)$, total plant leaf area $\left(13818 \mathrm{~cm}^{2}\right)$, internodes/plant $(22.2)$, and internode length $(8.0 \mathrm{~cm})$ (Table 2$)$. Values of most parameters remained statistically at par with $50 \mathrm{mg} / \mathrm{L}$ NAA. Data obtained in $\mathrm{GS}_{2}$ indicated almost similar trend with 30 and $50 \mathrm{mg} / \mathrm{L}$ NAA producing the maximum plant height $(78.5$ and $77.4 \mathrm{~cm})$ leaves/plant (24.4 and 23.0), total plant leaf area (10946 and 10038 $\mathrm{cm}^{2}$ ), internodes/plant (19.8 and 18.5), and internode length (5.6 and $5.2 \mathrm{~cm}$, accordingly) and remained statistically alike with each other for most parameters. Data also indicated that the maximum concentration of NAA (110 mg/L) led to reduced plant height (50.7 and $45.1 \mathrm{~cm})$, leaves/plant (18.4 and 14.5), total plant leaf 
area (5048 and $\left.4529 \mathrm{~cm}^{2}\right)$, internodes/plant (16.4 and 14.0), and internode length (5.2 and $4.3 \mathrm{~cm})$ in $\mathrm{GS}_{1}$ and $\mathrm{GS}_{2}$, respectively. However, results were statistically alike at control (0 mg NAA/L) for most parameters. Data pooled over two growing seasons indicated gain in most parameters determining vegetative growth in response to certain NAA concentration (mostly up to $30 \mathrm{mg} / \mathrm{L})$. Additional rise in NAA concentration (> 30 $\mathrm{mg} / \mathrm{L}$ ) had a supressing effect on most of parameters. This was also apparent from a quadratic relationship between plant height, leaves/plant, total plant leaf area, internodes/plant, internode length and NAA concentrations with $\mathrm{R}^{2}$ ranging from 80 to $98 \%$ (Fig. 2a-e).

Assessing impact of NAA on reproductive growth of Okra. NAA application induced a highly significant $(\mathrm{P} \leq 0.001)$ impact on earliness to flowering in both the growing seasons. Days required to first flowering ranged between 53.0-72.7 in $\mathrm{GS}_{1}$ and 51.1-70.7 in $\mathrm{GS}_{2}$ (Table $3)$. The plants without NAA application (i.e., control) exhibited delayed onset of first flowering significantly and took 60.0 and 58.0 days, whereas earlier start of flowering (53.0, 51.1 days) was recorded with $10 \mathrm{mg} / \mathrm{L}$ NAA concentration in $\mathrm{GS}_{1}$ and $\mathrm{GS}_{2}$, respectively. NAA applied at $30 \mathrm{mg} / \mathrm{L}$ appeared second most influential concentration in initiating early flowering (55.8 and
52.6 days) in plants during both the seasons. Data further indicated a strong quadratic link $\left(\mathrm{R}^{2}=96 \%\right)$ between days required to first flowering and NAA concentrations (Fig. 2f). In conclusion, onset of first flowering advanced with lowest NAA concentration and gradually delayed with increase in NAA concentration till $110 \mathrm{mg} / \mathrm{L}$ and produced maximum delay in first flowering in $\mathrm{GS}_{1}$ and $\mathrm{GS}_{2}$, respectively.

Assessing impact of NAA on pod characteristics. Parameters determining the pod characteristics were significantly $(\mathrm{P}<0.001)$ influenced by NAA application in both seasons. Maximum pod length (11.0 and 12.3 $\mathrm{cm})$ was noted with the foliar application of $30 \mathrm{mg}$ $\mathrm{NAA} / \mathrm{L}$ among the treatments apart from $10 \mathrm{mg} \mathrm{NAA} / \mathrm{L}$ $(10.7$ and $12.0 \mathrm{~cm})$ and $50 \mathrm{mg} \mathrm{NAA} / \mathrm{L}(10.1$ and 11.4 $\mathrm{cm}$ ) in $\mathrm{GS}_{1}$ and $\mathrm{GS}_{2}$, respectively (Table 3). Similarly, NAA concentration (30-50 mg/L) exhibited major increase in pod diameter and pod fresh weight and ranged between $14.3-16.0 \mathrm{~mm}$ and $15.2-17.6 \mathrm{~g}$, respectively across both the seasons. However, statistically both NAA treatments were alike. The absence of NAA application (control) produced minimum pod length $(8.9$ and $10.2 \mathrm{~cm})$, pod diameter (9.3 and $10.6 \mathrm{~mm}$ ), and pod fresh weight (6.8 and 8.1 g) in $\mathrm{GS}_{1}$ and $\mathrm{GS}_{2}$, respectively. Data also indicated that higher concentration of NAA $(70-110 \mathrm{mg} / \mathrm{L})$

Table 2. Effect of naphthalene acetic acid (NAA) concentrations on the vegetative growth of Okra during two growing seasons.

\begin{tabular}{|c|c|c|c|c|c|}
\hline NAA (mg/L) & $\begin{array}{l}\text { Plant height } \\
(\mathrm{cm})\end{array}$ & $\begin{array}{l}\text { Leaves/ } \\
\text { plant }\end{array}$ & $\begin{array}{l}\text { Total plant leaf } \\
\text { area }\left(\mathrm{cm}^{2}\right)\end{array}$ & $\begin{array}{l}\text { Internodes/ } \\
\text { plant }\end{array}$ & $\begin{array}{l}\text { Internode } \\
\text { length }(\mathrm{cm})\end{array}$ \\
\hline \multicolumn{6}{|l|}{$\mathrm{GS}_{1} \dagger$} \\
\hline 0 & $52.5 \mathrm{e}$ & $18.8 \mathrm{~d}$ & $6161 \mathrm{~cd}$ & $13.4 \mathrm{~d}$ & $4.9 \mathrm{f}$ \\
\hline 10 & $73.0 \mathrm{c}$ & $23.9 \mathrm{c}$ & $10102 \mathrm{~b}$ & $18.1 \mathrm{abc}$ & $7.7 \mathrm{~b}$ \\
\hline 30 & $84.0 \mathrm{a}$ & $29.1 \mathrm{a}$ & $12314 \mathrm{ab}$ & $22.2 \mathrm{a}$ & $8.0 \mathrm{a}$ \\
\hline 50 & $82.8 \mathrm{a}$ & $28.5 \mathrm{ab}$ & $13818 \mathrm{a}$ & $20.9 \mathrm{ab}$ & $7.6 \mathrm{~b}$ \\
\hline 70 & $78.0 \mathrm{~b}$ & $23.6 \mathrm{bc}$ & $10661 \mathrm{~b}$ & $19.8 \mathrm{abc}$ & $7.0 \mathrm{c}$ \\
\hline 90 & $67.0 \mathrm{~d}$ & $19.7 \mathrm{~cd}$ & $7361 \mathrm{c}$ & $17.2 \mathrm{bcd}$ & $5.9 \mathrm{~d}$ \\
\hline 110 & $50.7 \mathrm{e}$ & $18.4 \mathrm{~d}$ & $5048 \mathrm{~d}$ & $16.4 \mathrm{~cd}$ & $5.2 \mathrm{e}$ \\
\hline $\operatorname{LSD}(\mathrm{P} \leq 0.05)$ & 4.0 & 5.0 & 2313.6 & 4.1 & 0.13 \\
\hline \multicolumn{6}{|l|}{$\mathrm{GS}_{2}$} \\
\hline 0 & $49.3 \mathrm{~d}$ & $15.7 \mathrm{~d}$ & $4715 \mathrm{c}$ & $11.0 \mathrm{~d}$ & $4.0 \mathrm{f}$ \\
\hline 10 & $69.8 \mathrm{~b}$ & $20.1 \mathrm{bc}$ & $7734 \mathrm{~b}$ & $15.8 \mathrm{bc}$ & $5.3 \mathrm{~b}$ \\
\hline 30 & $78.5 \mathrm{a}$ & $24.4 \mathrm{a}$ & 10946 a & $19.8 \mathrm{a}$ & $5.6 \mathrm{a}$ \\
\hline 50 & $77.4 \mathrm{a}$ & $23.0 \mathrm{ab}$ & $10038 \mathrm{a}$ & $18.5 \mathrm{ab}$ & $5.2 \mathrm{bc}$ \\
\hline 70 & $71.3 \mathrm{~b}$ & $21.0 \mathrm{~b}$ & $7934 \mathrm{~b}$ & $17.4 \mathrm{abc}$ & $5.0 \mathrm{c}$ \\
\hline 90 & $59.2 \mathrm{c}$ & $17.4 \mathrm{~cd}$ & $5842 \mathrm{c}$ & $14.8 \mathrm{bc}$ & $4.7 \mathrm{~d}$ \\
\hline 110 & $45.1 \mathrm{e}$ & $14.5 \mathrm{~d}$ & $4529 \mathrm{c}$ & $14.0 \mathrm{~cd}$ & $4.3 \mathrm{e}$ \\
\hline $\operatorname{LSD}(\mathrm{P} \leq 0.05)$ & 3.4 & 3.3 & 1663.5 & 3.7 & 0.20 \\
\hline
\end{tabular}

Means with unlike letter(s) are significantly different; $\dagger=$ Growing season of $2014 ; \ddagger=$ Growing season of 2015. 
Table 3. Effect of naphthalene acetic acid (NAA) concentrations on the reproductive growth, pod characteristics and yield of Okra during two growing seasons

\begin{tabular}{|c|c|c|c|c|c|c|}
\hline NAA (mg/L) & $\begin{array}{l}\text { Onset of first } \\
\text { flowering }\end{array}$ & $\begin{array}{l}\text { Pod length } \\
(\mathrm{cm})\end{array}$ & $\begin{array}{l}\text { Pod diameter } \\
(\mathrm{mm})\end{array}$ & $\begin{array}{l}\text { Pod fresh } \\
\text { weight }(g)\end{array}$ & $\begin{array}{l}\text { Total } \\
\text { pods/plant }\end{array}$ & $\begin{array}{l}\text { Pod yield } \\
\text { (t/ha) }\end{array}$ \\
\hline \multicolumn{7}{|l|}{$\overline{\mathrm{GS}} 1 \dagger$} \\
\hline 0 & $60.0 \mathrm{c}$ & $8.9 \mathrm{c}$ & $9.3 \mathrm{e}$ & $6.8 \mathrm{f}$ & $11.5 \mathrm{~g}$ & $5.8 \mathrm{f}$ \\
\hline 10 & $53.0 \mathrm{f}$ & $10.7 \mathrm{a}$ & $13.0 \mathrm{c}$ & $12.7 \mathrm{~d}$ & $22.3 \mathrm{a}$ & $15.7 \mathrm{~d}$ \\
\hline 30 & $55.8 \mathrm{e}$ & $11.0 \mathrm{a}$ & $14.7 \mathrm{a}$ & $16.3 \mathrm{a}$ & $21.5 \mathrm{~b}$ & $20.8 \mathrm{a}$ \\
\hline 50 & $57.0 \mathrm{de}$ & $10.1 \mathrm{ab}$ & $14.3 \mathrm{a}$ & $15.2 \mathrm{ab}$ & $19.9 \mathrm{c}$ & $19.8 \mathrm{~b}$ \\
\hline 70 & $59.1 \mathrm{~cd}$ & $9.6 \mathrm{bc}$ & $13.5 \mathrm{~b}$ & $14.3 \mathrm{bc}$ & $18.3 \mathrm{~d}$ & $18.0 \mathrm{c}$ \\
\hline 90 & $67.0 \mathrm{~b}$ & $9.5 \mathrm{bc}$ & $13.1 \mathrm{bc}$ & $13.5 \mathrm{~cd}$ & $14.0 \mathrm{e}$ & $14.8 \mathrm{~d}$ \\
\hline 110 & $72.7 \mathrm{a}$ & $9.1 \mathrm{c}$ & $11.8 \mathrm{~d}$ & $10.5 \mathrm{e}$ & $13.3 \mathrm{f}$ & $10.7 \mathrm{e}$ \\
\hline $\operatorname{LSD}(\mathrm{P} \leq 0.05)$ & 2.6 & 0.97 & 0.51 & 1.4 & 0.67 & 1.0 \\
\hline \multicolumn{7}{|l|}{ GS2 } \\
\hline 0 & $58.0 \mathrm{c}$ & $10.2 \mathrm{c}$ & $10.6 \mathrm{e}$ & $8.1 \mathrm{f}$ & $10.3 \mathrm{f}$ & $5.0 \mathrm{e}$ \\
\hline 10 & $51.1 \mathrm{e}$ & $12.0 \mathrm{a}$ & $13.0 \mathrm{~d}$ & $14.0 \mathrm{~d}$ & $19.7 \mathrm{a}$ & $15.0 \mathrm{c}$ \\
\hline 30 & $52.6 \mathrm{e}$ & $12.3 \mathrm{a}$ & $16.0 \mathrm{a}$ & $17.6 \mathrm{a}$ & $18.9 \mathrm{~b}$ & $19.0 \mathrm{a}$ \\
\hline 50 & $53.3 \mathrm{de}$ & $11.4 \mathrm{ab}$ & $15.6 \mathrm{ab}$ & $16.5 \mathrm{ab}$ & $18.5 \mathrm{~b}$ & $18.4 \mathrm{a}$ \\
\hline 70 & $56.0 \mathrm{~cd}$ & $10.9 \mathrm{bc}$ & $14.8 \mathrm{bc}$ & $15.6 \mathrm{bc}$ & $17.3 \mathrm{c}$ & $16.7 \mathrm{~b}$ \\
\hline 90 & $63.5 \mathrm{~b}$ & $10.4 \mathrm{bc}$ & $14.4 \mathrm{c}$ & $14.8 \mathrm{~cd}$ & $13.4 \mathrm{~d}$ & $14.1 \mathrm{c}$ \\
\hline 110 & $70.7 \mathrm{a}$ & $10.0 \mathrm{c}$ & $13.1 \mathrm{~d}$ & $11.8 \mathrm{e}$ & $12.8 \mathrm{e}$ & $9.0 \mathrm{~d}$ \\
\hline $\operatorname{LSD}(\mathrm{P} \leq 0.05)$ & 3.4 & 1.0 & 0.79 & 1.2 & 0.60 & 1.5 \\
\hline
\end{tabular}

Means with unlike letter(s) are significantly different; $\dagger=$ Growing season of 2014; $\ddagger=$ Growing season of 2015 .

negatively affected the pod length, diameter and fresh weight among all the treatments in both the growing seasons. The combined data from two growing seasons further indicated a strong quadratic relationship between pod length, diameter, fresh weigh and NAA concentration with $\mathrm{R}^{2}$ ranging from $>63 \%$ to $90 \%$ (Fig. $2 \mathrm{~g}$-h $\&$ Fig. 3a). In other words, all these parameters increased positively with NAA application up to certain concentration $(30 \mathrm{mg} / \mathrm{L})$ and reduced with further rise in NAA concentration. These results indicated that higher concentration of NAA $(\geq 70 \mathrm{mg} / \mathrm{L})$ may induce a negative effect on pod characteristics. However, NAA application is still better than control $(0 \mathrm{mg} \mathrm{NAA} / \mathrm{L})$ which overall resulted into minimum values of these parameters.

Assessing impact of NAA on yield formation in Okra. The reposted data showed significant $(\mathrm{P} \leq 0.001)$ effect of NAA application on the yield formation in Okra. The significantly greater (22.3 and 19.7$)$ pods/plant were observed in treatments receiving $10 \mathrm{mg} / \mathrm{L} \mathrm{NAA}$ followed by $30 \mathrm{mg} / \mathrm{L}$ NAA producing 21.5 and 18.9 pods/plant in $\mathrm{GS}_{1}$ and $\mathrm{GS}_{2}$, respectively (Table 3). On the other hand, foliar application of 30 and $50 \mathrm{mg} / \mathrm{L}$ NAA produced maximum pod yields during both the seasons and ranged from 18.4 to $20.8 \mathrm{t} / \mathrm{ha}$. However, results were statistically alike in $\mathrm{GS}_{2}$ between these two
NAA treatments. The control treatment $(0 \mathrm{mg}$ NAA/L $)$ exhibited lowest (11.5 and 10.3) pods/plant and minimum pod yield (5.8 and 5.0 t/ha) in $\mathrm{GS}_{1}$ and $\mathrm{GS}_{2}$, respectively among all the treatments. Data showed the quadratic relationship between pods/plant, pod yield and different concentration of NAA $\left(\mathrm{R}^{2}=86-93 \%\right)$ as illustrated by Fig. 3b-c. The results overall suggested that pod production enhanced with lower NAA concentrations (10-30 mg/L). Further concentration of NAA induced a gradual declination in pod yield.

Assessing correlations between yield and yieldcontributing parameters of Okra. Data revealed significant $(\mathrm{P} \leq 0.001)$ inter-relationships among the parameters (Fig. 4). There existed positive very strong correlations $(r \geq 0.70)$ between plant height and leaves/plant, total plant leaf area, internodes/plant, internode length, pod fresh weight, and pods/plant ( $\mathrm{r}=$ $0.77-0.88$ ), between leaves/plant and total plant leaf area, internodes/plant, internode length, and pods/plant $(\mathrm{r}=0.72-0.96)$, between total plant leaf area and internodes/plant, internode length, and pods/plant $(\mathrm{r}=$ 0.77-0.80), between internodes/plant and internode length $(\mathrm{r}=0.73)$, between pod diameter and pod fresh weight $(r=0.93)$, between pods/plant and internode length $(r=0.72)$. 

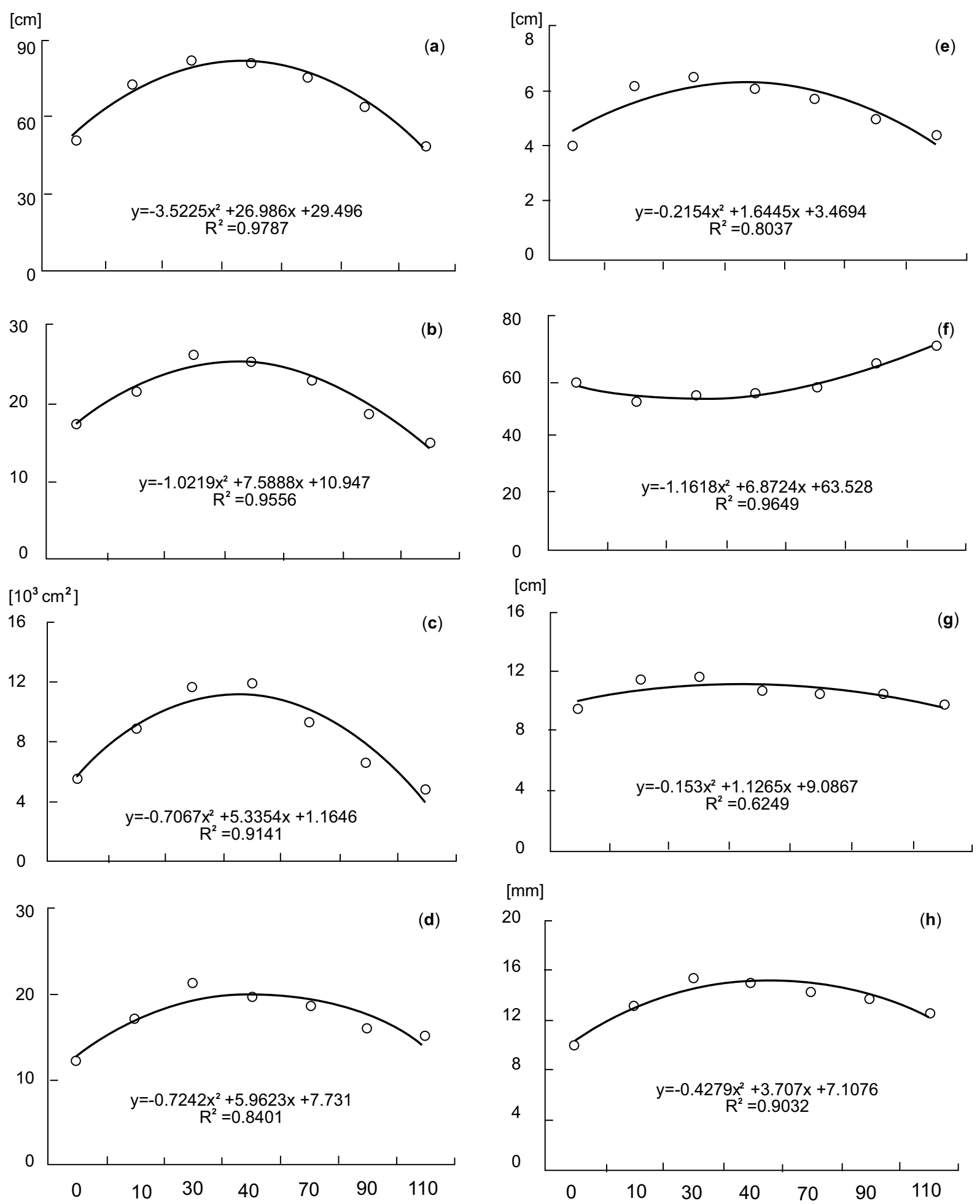

NAA Concentration ( $\mathrm{mg} / \mathrm{L})$

Fig. 2. Effect of different concentrations of naphthalene acetic acid (NAA) on (a) plant height, (b) leaves/plant, (c) total plant leaf area, (d) internodes/plant, (e) internode length, (f) onset of first flowering, (g) pod length, (h) pod diameter. 

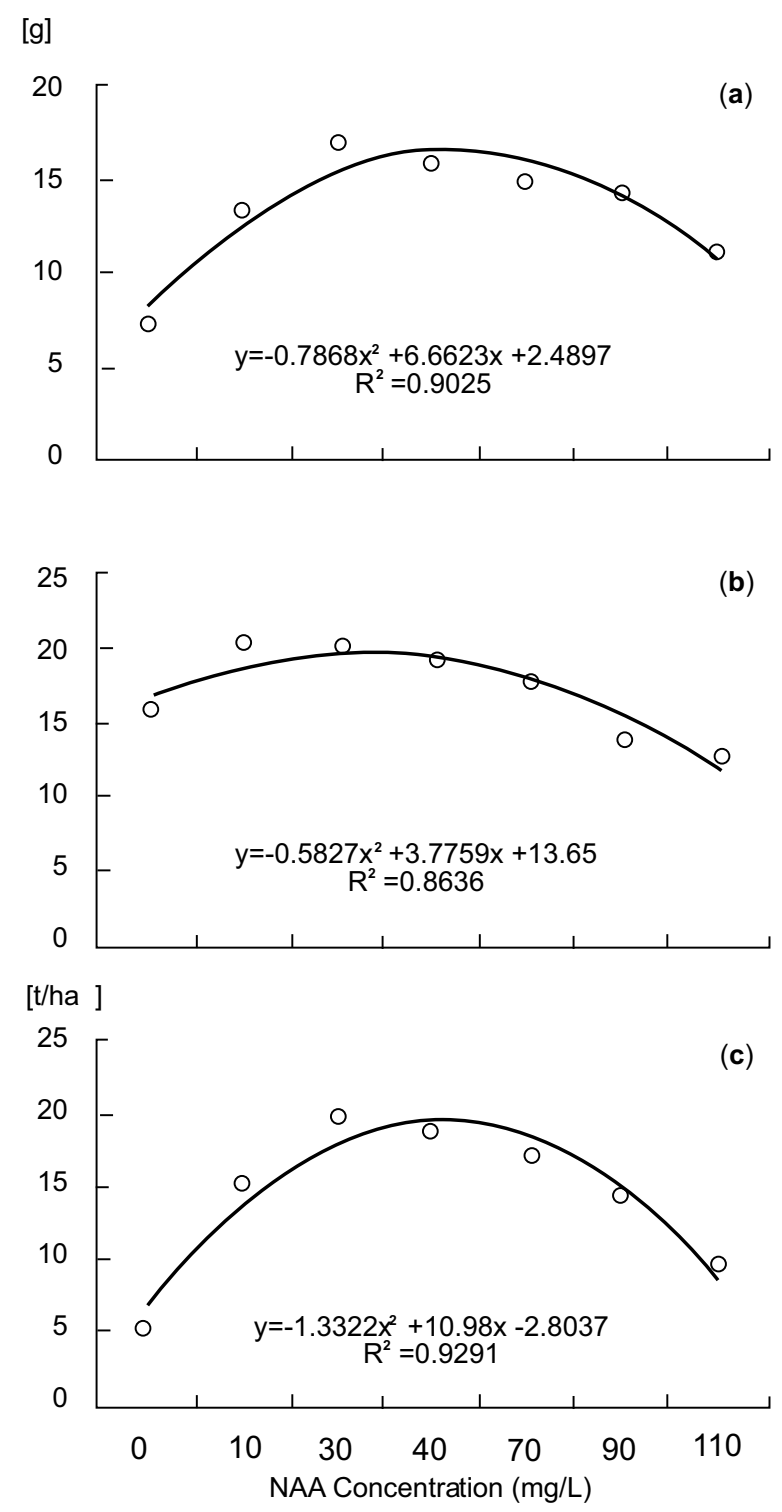

Fig. 3. Effect of different concentrations of naphthalene acetic acid (NAA) on (a) pod fresh weight, (b) total pods/plant, (c) pod yield.

Furthermore, fairly strong positive correlations $(0.40$ $\leq \mathrm{r} \leq 0.70$ ) existed between plant height and pod length, pod diameter $(\mathrm{r}=0.47-0.68)$; between leaves/plant and pod diameter, pod fresh weight $(\mathrm{r}=0.47-0.53)$, between total plant leaf area and pod diameter, pod fresh weight, pods/plant $(\mathrm{r}=0.60-0.64)$, between internodes/plant and pod diameter, pod fresh weight $(\mathrm{r}=0.47-0.53)$, between internode length and pod fresh weight $(\mathrm{r}=$ 0.42 ), between pod length and pod diameter, pod fresh weight, pods/plant $(\mathrm{r}=0.43-0.65)$, between pod fresh weight and pods/plant $(\mathrm{r}=0.45)$.

Data also exposed very strong negative correlations $(\mathrm{r}$ $=-0.80$ ) between pods/plant and onset of first flowering. There existed fairly strong negative correlations (- 0.40 $\leq \mathrm{r} \leq-0.70$ ) between onset of first flowering and plant height, leaves/plant, total plant leaf area, pod length, pod fresh weight with " $r$ " values ranging from -0.40 to -0.67 .

Data further revealed very strong positive correlations $(r \geq 0.70)$ between pod yield and most of the parameters including plant height, leaves/plant, total plant leaf area, internodes/plant, pod diameter, pod fresh weight with value of $r$ ranging between 0.70 to 0.92 (Fig. 4). Data also showed reasonably strong positive correlations $(0.40 \leq \mathrm{r} \leq 0.70)$ between pod yield and pod length, pods/plant $(\mathrm{r} \leq 0.48-0.64)$. Pod yield indicated strong negative relationship $(r=-0.51)$ with the onset of first flowering amongst the rest of parameters.

This study aimed to assess the influence of NAA on the growth and yield production in Okra. Foliar application of NAA positively affected the parameters determining the vegetative, reproductive and yield formation in Okra. Lower concentration of NAA (30-50 $\mathrm{mg} / \mathrm{L}$ ) induced maximum plant height, leaves/plant, total plant leaf area, internodes/plant, internode length, pod length, pod diameter, pod fresh weight, and pod yield. Furthermore, results indicated the mean increase in plant height (59.5 and 57.2\%), number of leaves/plant (50.4 and $45.5 \%$,), total plant leaf area (113.9 and 119.4 $\%$ ), internodes/plant (72.5 and 61.6\%), internode length (53.2 and $44.5 \%$ ), pod diameter (53.5 and $49.9 \%$ ), pod fresh weight (126.8 and $111.8 \%$ ), and pod yield (271.2 and $255.8 \%$ ) with the application of 30 and 50 $\mathrm{mg} / \mathrm{L}$ NAA, respectively, over control (0 mg NAA/L). However, NAA concentration of 10 and $30 \mathrm{mg} / \mathrm{L}$ increased the pod length up to 19.0 and $21.07 \%$, and pods/plant up to 31.1 and $27.9 \%$, respectively over control (0 mg NAA/L).

The increase in vegetative growth could be due to stimulated cell multiplication and elongation of internodes (Dhage et al., 2011). Studies by Abdo and Abdel-Aziz (2009) and Kumar et al. (2018) also revealed that exogenous application of NAA up to $50 \mathrm{mg} / \mathrm{L}$ improved the overall vegetative growth and leaf area of the plant. Furthermore, more pod yield with lower NAA concentrations ( 30 and $50 \mathrm{mg} / \mathrm{L}$ ) might be due to 


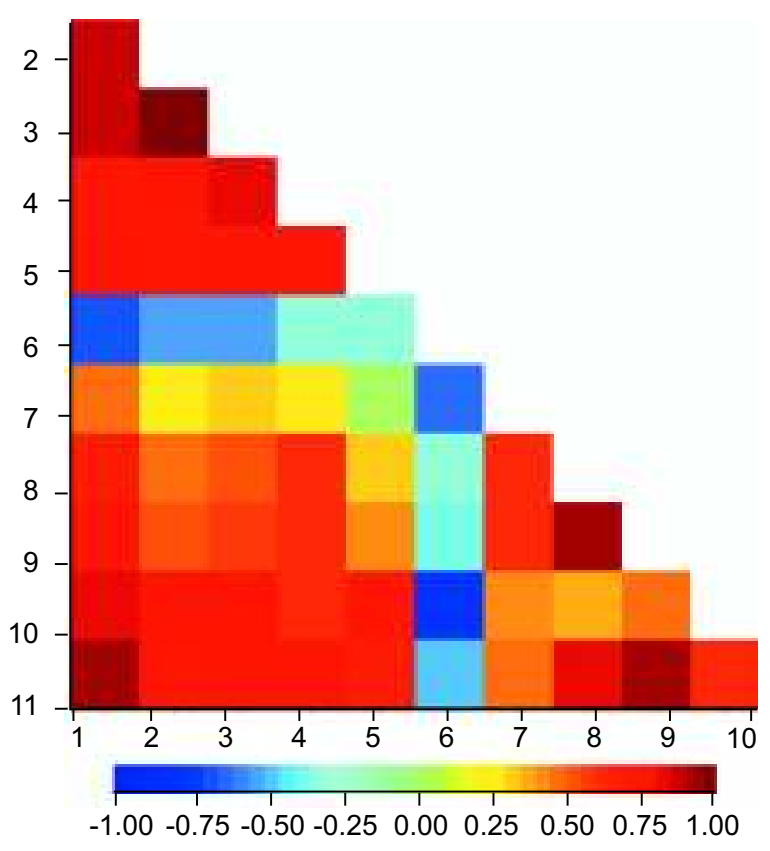

Fig. 3. A colour heat map exposing correlations among growth and yield-determining parameters of Okra, where:

$1=$ Plant height; 2 = Leaves/plant; $3=$ Total plant leaf area; $4=$ Internodes/plant; $5=$ Internode length; $6=$ Onset of first flowering; $7=$ Pod length; $8=$ Pod diameter; $9=$ Pod fresh weight; $10=$ Total pods/plant; $11=$ Pod yield. Colour bars represent the strength of the Pearson's correlation coefficient " $r$ ".

better translocation of photo-assimilates to the developing pods and seeds (Ravat and Makani, 2015). This could also be due to enhanced source sink relationship initiated by exogenous NAA application that in turn stimulated the heavier build-up of sufficient food reserves thereby helping in effective pod development and ultimately enhancing the pod yield (Huang et al., 2018). Various studies have reported the effectiveness of NAA towards inducing pod production in other crops including lablab bean (Uddin et al., 1994), pigeonpea (Rao and Narayan, 1997), and chickpea (Karim, 2005). Our results were supported by Meena (2015) and Singh et al. (2017), who also accounted increase in most of the growth traits, yield-components and overall pod yield in Okra with the application of NAA.
Furthermore, it was observed that application of NAA at higher concentrations $(>50 \mathrm{mg} / \mathrm{L}$ ) had a supressing effect on most of parameters. This was also apparent from a quadratic relationship between most of parameters and NAA concentrations. For instance, the onset of first flowering became 7 and 5 days earlier with the application of lower rates of NAA (10 and $30 \mathrm{mg} / \mathrm{L}$, respectively) and gradually delayed with rise in NAA concentration till the maximum level $(110 \mathrm{mg} / \mathrm{L})$ and produced maximum delay (12.7 days) in the start of first flowering over control (0 mg NAA/L) (Mustafa et al., 2016). This could be associated with suppression of metabolic pathways responsible for early flowering at higher NAA concentration (Huang et al., 2018). It was interesting to note that results of NAA $(110 \mathrm{mg} / \mathrm{L})$ and control ( $0 \mathrm{mg} \mathrm{NAA} / \mathrm{L})$ were statistically alike for most parameters. However, NAA application was still better than control $(0 \mathrm{mg} \mathrm{NAA} / \mathrm{L})$ which overall led to minimum vegetative growth and pod yield. This was evident from the fact that different NAA concentrations $(10,30,50,70,90,110 \mathrm{mg} / \mathrm{L})$ increased the pod yield in the range of $185.8,271.2,255.8,224.3,169.7$ and $83.6 \%$, respectively over control ( $0 \mathrm{mg} \mathrm{NAA} / \mathrm{L})$.

Analysis of correlation coefficients revealed strong and positive inter-relationships between most of the parameters (Fatima et al., 2019). Highly strong association between pod yield and growth parameters viz., plant height, leaves/plant, total plant leaf area, internodes/plant, internode length and yield-components such as pod diameter, pod fresh weight, and number of pods/plant revealed that these are the vital yield determinants in Okra (Falusi et al., 2012). Negative association between pod yield and the onset of first flowering suggested that a delay in flowering might have a detrimental impact on yield production in Okra mainly due to shortening of the reproductive growth period influenced by uncongenial environmental conditions (Bruns, 2009). It was inferred that yield constitution in Okra is influenced by multiple yieldcontributing traits and their mutual inter-associations. Selecting for such traits would assist in formulating an indirect selection criterion for yield improvement in Okra (Fatima et al., 2019).

\section{Conclusion}

This study clearly indicated that foliar application of NAA had a marked impact on parameters determining the vegetative, reproductive, and yield formation in 
Okra. Overall, application of NAA in the range of 30-50 $\mathrm{mg} / \mathrm{L}$ appeared the best levels for increased pod yield. Results concluded that yield-contributing characters and pod yield of Okra could be manipulated by the application of NAA. Therefore, foliar application of NAA at the rate of $30-50 \mathrm{mg} / \mathrm{L}$ may be recommended for ensuring better Okra yield.

\section{Acknowledgement}

We thanks the staff of Department of Soil and Environmental Sciences, the University of Agriculture, Peshawar, Pakistan for performing the soil analyses.

Conflict of Interest. The authors declare no conflict of interest.

\section{References}

Abdo, F.A., Abdel-Aziz, E.S.A. 2009. Response of soybean to foliar spraying with growth regulators mixture and zinc. Egyptian Journal of Applied Science, 24: 215-238.

Abdoli, M., Saeidi, M., Jalali-Honarmand, S., Azhand, M. 2013. The effect of foliar application of indol3 -acetic acid (IAA) and roles of ear photosynthesis on grain yield production of two wheat cultivars (Triticum aestivum L.) under post anthesis water deficit. International Research Journal of Applied and Basic Sciences, 4: 1406-1413.

Adelakun, O.E., Oyelade, O.J. 2011. Chapter 99 Chemical and antioxidant properties of okra (Abelmoschus esculentus Moench) seed. In: Nuts and Seeds in Health and Disease |Prevention, Preedy, V.R., Watson, R.R., Patel, V.B., (eds.), pp. 841-846, Academic Press, USA.

Anjum, M.A., Zahir, Z.A., Arshad, M., Ashraf, M. 2011. Isolation and screening of rhizobia for auxin biosynthesis and growth promotion of mung bean (Vigna radiata L.) seedlings under axenic conditions. Soil and Environment, 30: 18-26.

Babatola, L.A. 2006. Effect of NPK 15:15:15 on the performance and storage life of okra (Abelmoschus esculentus). In: Proceedings of the Horticultural Society of Nigeria Conference, 125-128.

Benchasri, S. 2012. Okra (Abelmoschus esculentus (L.) Moench) as a valuable vegetable of the world. Ratarstvo i povrtarstvo - Journal on Field and Vegetable Crops Research, 49: 105-112.
Bruns, H.A. 2009. A survey of factors involved in crop maturity. Agronomy Journal, 101: 60-66.

Dawood, M.G., Sadak, M.S. 2008. Physiological response of canola plants (Brassica napus) to tryptophan and benzylalanine. Seria Agronomie, 50: 198-207.

Dhage, A.A., Nagre, P.K., Bhangre, K.K., Papu, A.K. 2011. Effect of plant growth regulators on growth and yield parameters of Okra. Asian Journal of Horticulture, 6: 170-172.

Falusi, O.A., Dangana, M.C., Daudu, O.Y., de-Silva, J.A.T. 2012. Studies on morphological and yield parameters of three varieties of Nigerian Okra [Abelmoschus esculentus (L.) Moench]. Journal of Horticulture and Forestry, 4: 126-128.

Fatima, S., Khan, M.S., Nadeem, M., Khan, I., Waseem, K., Nisar, M., Iqbal, M. 2019. Interactive effects of genotype and nitrogen on the phenology and yield determination of Okra (Abelmoschus esculentus L.). International Journal of Plant Production, 13: 73?90.

Gemede, H.F., Ratta, N., Haki, G.D., Woldegiorgis, A.Z., Beyene, F. 2015. Nutritional quality and health benefits of Okra (Abelmoschus esculentus): a review. Journal of Food Processing and Technology, 6: 1-6.

Gunawardhana, M.D.M., de-Silva, C.S. 2011. Impact of temperature and water stress on growth yield and related biochemical parameters of Okra. Journal of Tropical Agricultural Research, 23: 77-83.

Huang, Y., Zeng, X., Cao, H. 2018. Hormonal regulation of floret closure of rice (Oryza sativa). PLoS One, 13: 0198828.

Husen, A., Iqbal, M., Aref, I.M. 2016. IAA-induced alteration in growth and photosynthesis of pea (Pisum sativum L.) plants grown under salt stress. Journal of Environmental Biology, 37: 421-429.

Iderawumi, A.M., Friday, C.E., Mubo, O.A. 2017. Nutritional evaluation of Okra pod and mother soil as influenced by sawdust ash, ammonium nitrate and NPK. Environment and Ecology Research, 5: 334-339.

IPGRI (The International Plant Genetic Resources Institute). 1991. International crop network series. Report of an international workshop on Okra genetic resources. International Board for Plant Genetic Resources, Rome. 
Karim, M.F. 2005. Physiological and biochemical responses of chickpea (Cicer arietenum L.) following application of fertilizers and growth regulators. Ph.D. Thesis. Department of Botany, Dhaka University, Dhaka-1000, Bangladesh.

Keeney, D.R., Nelson, D.W. 1982. Nitrogen-inorganic forms. In: Methods of Soil Analysis, Part-2, Page, A.L. Miller, R.H. Keeney D.R. (eds.), pp. 643-698, American Society of Agronomy, Madison, W.I., USA.

Khan, M.A., Sajid, M., Hussain, Z., Rab, A., Marwat, K.B., Wahid, F.I., Bibi, S. 2013. How nitrogen and phosphorus influence the phenology of Okra. Pakistan Journal of Botany, 45: 479-482.

Knudsen, D., Peterson, G.A., Pratt, P.F. 1982. Lithium, sodium and potassium determination. In: Methods of Soil Analysis, Part-2, Page, A.L., Miller, R.H., Keeney, D.R. (eds.), pp. 228-239. American Society of Agronomy, Madison, W.I., USA.

Koehler, F.E., Moodie, C.D., McNeal, B.L. 1984. Laboratory Manual for Soil Fertility. Washington State University, Department of Agronomy and Soils. Pullman, Washington, USA.

Kumar, V., Jat, P.K., Mukherjee, S., Singh, S.P. 2018. Role of plant growth regulator's in strawberry. International Journal of Chemical Studies, 6: 949954.

Liu, L., Guo, G., Wang, Z., Ji, H., Mu, F., Li, X. 2014. Auxin in plant growth and stress responses. In: Phytohormones: A Window to Metabolism, Signaling and Biotechnological Applications, Phan, L.S., Tran, S., Pal (eds.), pp. 35. Springer Science + Business media New York, USA.

Maity, U., Dutta, P., Layek, B. 2016. Effect of plant growth regulators on growth, yield and quality of Okra (Abelmoschus esculentus (L.) Moench). Journal of Agroecology and Natural Resource Management, 3: 251-253.

Majda, M., Robert, S. 2018. The role of auxin in cell wall expansion. International Journal of Molecular Sciences, 19: 1-21.

Malik, C.P. 1999. Introduction in Advances in Plant Hormones Research: Indian Scenario. Agro Botanica, New Delhi, India, pp. 14-15.

Meena, O.P. 2015. A review: role of plant growth regulators in vegetable production. International Journal of Agricultural Science Research, 5: 7184.
Mustafa, A.,Hussain, A., Naveed, M., Ditta, A., Nazli, Z.E.H., Sattar, A. 2016. Response of Okra (Abelmoschus esculentus L.) to soil and foliar applied L-tryptophan. Soil and Environment, 35: 76-84.

Nelson, D.W., Sommers, L.E. 1982. Total carbon, organic carbon and organic matter. In: Methods of Soil Analysis, Part-2, Page, A.L., Miller, R.H., Keeney, D.R. (eds.), pp. 539-577. American Society of Agronomy, Madison, W.I., USA.

Olsen, S.R., Sommers, C.E. 1982. Phosphorus in soil Analysis. In: Methods of Soil Analysis, Part-2, Miller, A.L., Keeney, R.H., Keeney, D.R. (eds.), pp. 403-430. American Society of Agronomy, Madison, W.I., USA.

Payne, R.W., Murray, D.A., Harding, S.A., Baird, D.B., Soutar, D.M. 2009. GenStat for Windows $\left(12^{\text {th }}\right.$ edition) Introduction. VSN International, Hemel, Hempstead.

Raddadi, N., Cherif, A., Boudabous, A., Daffonchio, D. 2008. Screening of plant growth promoting traits of Bacillus thuringiensis. Annals of Microbiology, 58: 47-52.

Rao, J.S.P., Narayanan, A. 1997. Effect of water, light stress and foliar application of auxins on flower abscission and seed yield of pigeon pea. Madras Agricultural Journal, 84: 127-129.

Ravat, A.K., Makani, N. 2015. Influence of plant growth regulators on growth, seed yield and seed quality in Okra (Abelmoschus esculentus (L.) Moench) cv. GAO-5 under middle Gujarat condition. International Journal of Agricultural Sciences, 11: 151-157.

Roy, D.S., Kabir, J., Chatterjee, R., Mitra, S.K. 1991. Effect of postharvest foliar spray of some chemicals in storage behaviour of onion. Onion Newsletter for the Tropics, 3: 23-25.

Singh, D., Vadodaria, J.R., Morwal, B.R. 2017. Effect of GA3 and NAA on yield and quality of Okra (Abelmoschus esculentus L). Journal of Krishi Vigyan, 6: 65-67.

Uddin, M.M., Quadir, M.A., Choudhury, A.R., Choudhury, M.K. 1994. Effects of growth regulators on growth and pod yield of lablab bean grown in summer. Journal of Bangladesh Agricultural University, 4: 79-85.

Unamba, C.I.N., Ezeibekwe, I.O., Mbagwu, F.N. 2009. Comparative effect of the foliar spray and seed 
soaking application method of gibberellic acid on the growth of Abelmoschus esculentus (Okra dwarf). Journal of American Science, 5: 133-140.

UPOV (Union for the Protection of New Varieties of Plants). 2018. http://www.upov.int

USDA (United States Department of Agriculture, Agricultural Research Service), 2018. USDA nutrient database for standard reference, Release 1 April 2018. Retrieved January 21, 2019, from http://ndb.nal.usda.gov/ndb/

Yadev, S.K., Dhanker, B.S. 2002. Performance of 'Varsha Uphar' cultivar of Okra as affected by sowing dates and plant geometry. Vegetable Science, 27: 70-74. 